\title{
Factorial design study of total petroleum contaminated soil treatment using land farming technique
}

\author{
Ehizonomhen S. Okonofua ${ }^{1}$, Kayode H. Lasisi ${ }^{2,3^{*}}$ (1) and Eguakhide Atikpo ${ }^{4}$
}

\begin{abstract}
Land farming technique was used to treat hydrocarbon contaminated soil collected from a crude oil spill sites in Edo State, Nigeria. Calibrated standard auger was used to collect soil samples from the site at depth below $30 \mathrm{~cm}$. The samples were characterized and classified. Cow dung and NPK fertilizer were added as additives to complement the nutriments of the soil samples before total petroleum hydrocarbon (TPH) quantification and remediation procedures. Factorial design was applied to vary the input parameters such as $\mathrm{pH}$, mass of substrate, moisture content and turning times of land farming so to ascertain the optimal conditions for the procedure. The result revealed that the in-situ TPH value was $5000 \mathrm{mg} \mathrm{kg}^{-1}$ on the average and after $90 \mathrm{~d}$ of treatment, TPH reduced to $646 \mathrm{mg} \mathrm{kg}^{-1}$. The turning rate, $\mathrm{pH}$, moisture content and mass of substrate hade $83,4.36,0.48$ and $0.046 \%$ contribution, respectively, for the degradation process using land farming treatment. Numerical optimization techniques applied in the optimum point for land farming input parameters to achieve predicted maximum removal of $99 \%$ were evaluated as $\mathrm{pH}$, mass of substrate, moisture content and turning rate to be $6.01,1 \mathrm{~kg}, 10 \%$ and 5 times in a week, respectively. TPH removed at this optimum point was $98 \%$ reducing from 5000 to $636 \mathrm{mg}$ $\mathrm{kg}^{-1}$. The high coefficient of determination $\left(r^{2}=0.9865\right)$ as observed in the closeness of predicted and experimental values reflects the reliability of the model and hence, land farming practice with close attention on turning rate as revealed by this study, is recommended for TPH contaminated soil remediation.
\end{abstract}

Keywords: Remediation, Factorial design, Soil contamination, Land farming, Optimization

\section{Introduction}

Advancement in technology, continuous urban sprawling and improved standard of living have over the years, caused a corresponding increase on energy demand, which is largely used in powering automobile and other related machines and appliances. Energy from coal, fossil fuel and some renewable sources like solar and biomass have been widely used with fossil fuel being the most utilized among them [1, 2]. Fuel is one of the major products of processed crude oil, rich in hydrocarbon

\footnotetext{
* Correspondence: senserltd@gmail.com

${ }^{2}$ Department of Civil and Environmental Engineering, Federal University of

Technology, Akure 340252, Nigeria

${ }^{3}$ Institute of Urban Environment, Chinese Academy of Sciences, Xiamen

361021, China

Full list of author information is available at the end of the article
}

content and is largely sort after for effective running of human daily activities. These activities have in one way or the other hampered the chain procedures of crude oil - drilling, refining, treatment, transportation and utilization which on the long run result in spillage, thus distorting several ecosystems and rendering most lands useless [3]. In Nigeria (especially the Niger Delta region - comprising of nine states), there has been oil spills resulting in soil contamination due to poor operation and management practices $[4,5]$. It is reported that about $13 \mathrm{Mt}$ of hydrocarbons are spilled which is caused largely by pipeline vandalism, destructive crude oil theft, operational spills and engineering failure (such as pipeline rupture), and uncivilized refining conditions [611]. The severity of damage done to these soils by

(c) The Author(s). 2021 Open Access This article is licensed under a Creative Commons Attribution 4.0 International License, which permits use, sharing, adaptation, distribution and reproduction in any medium or format, as long as you give

appropriate credit to the original author(s) and the source, provide a link to the Creative Commons licence, and indicate if changes were made. The images or other third party material in this article are included in the article's Creative Commons licence, unless indicated otherwise in a credit line to the material. If material is not included in the article's Creative Commons licence and your intended use is not permitted by statutory regulation or exceeds the permitted use, you will need to obtain permission directly from the copyright holder. To view a copy of this licence, visit http://creativecommons.org/licenses/by/4.0/. 
hydrocarbon spill is a function of diverse factors such as partition coefficient of the soil, permeability, absorption properties and chemical constituents of the hydrocarbon. Another source through which spillage occurs is through natural seeping in locations where hydrocarbon is found in sub-surface deposit to accidental discharge of crude oil onto ground surface and several other points of pollution, but irrespective of this source, once hydrocarbon spills into the soil, it alters both its physical and chemical properties [12-14], thus becoming harmful to plants, microorganism in the soils and humans.

Effective cleaning-up oil-contaminated soils by adopting some available technologies, is a viable option of remediation process and this is done to degrade hydrocarbon present in the soil. Hydrocarbon degradation is a process that involves the gradual weathering and removal of petroleum constituents especially the nonvolatile compounds from the contaminated location by using physical, chemical and biological methods for remediation of contaminated soils [15-17]. For instance, bioremediation which involves the utilization of effective microbes for hydrocarbon degradation has increasingly gained researchers interest in recent decades. The most frequently isolated and utilized hydrocarbon degrading microbes are genus Pseudomonas which degrade complex chains of hydrocarbon into smaller and less toxic compound. Also, fungi in the genera of Fusarium, Rhizopus and Penicillium have gained acceptance in treating hydrocarbon contaminated soil since Exxon Valdez spillage in 1980 [17, 18]. Land farming has been acknowledged as an effective and low-cost technology for abstraction of total petroleum hydrocarbons (TPHs) from soil [18-20]. It is reckoned to use less energy and it is not harmful to the environment, with reduced residue disposal problems [21]. Land farming treatment is the application of calculated organic and inorganic substrates on contaminated soil in order to mineralize the toxic substances in the soil $[22,23]$. Land farming is a concept that entails nutriments addition and replication of microbes, geared towards increasing the number and growth of microorganisms in order to accelerate bioremediation rate $[20,24,25]$. As microbes require sufficient major element like carbon, hydrogen, oxygen, nitrogen, and phosphorous for the development of macromolecules, fertilizer addition provides the bacterial with vital elements to thrive and reproduce. In some cases, sawdusts, animal dungs, and straws may supply bacterial with carbon sources [26]. Land farming techniques has been practiced in some regions of the world to bioremediate crude oil contamination in soils to minimize the health risk on human and the environment at large $[27,28]$. It has been used successfully to remove petroleum hydrocarbons at large scale [23, 29], and because of its simplicity in implementation, Niger Delta has also employed it. Unfortunately, with the handful of its application within Nigeria, there is still dearth of information on the efficient practice of land farming treatment for crude oil contaminated soils for effective remediation.

The effectiveness of land farming can be enhanced when environmental circumstances allow the growth of microbes, and this depends on some certain environmental parameters such as $\mathrm{pH}$, moisture content, nutrient availability, among others $[23,30]$. Factorial design (FD) is normally used in screening variables (both dependent and independent) and also in optimizing response surfaces. The latter is frequently used for experimental designs involving experimental procedures [31]. FD has been employed in some oil biodegradation studies of constituent's optimization that may induce the microbial debasement phenomenon hereby contributing to the progress of oil spill bioremediation process. Bhattacharya and Biswas [32] investigated the effect of various nutrients added to waste engine oil biodegradation of Bushnell-Haas medium using Ochrobactrum pseudintermedium bacterium. The data permit the development of an empirical model $(p<0.00672)$ through the application of a full FD for experimental work thus, describing the connection between dependent and independent variables. Jasmine and Mukherji [33] also assessed the treatment of refinery oily sludge using $2^{n}$ full FD via bioaugmentation and biostimulation processes. FD was also applied in the bioremediation of artificially contaminated soil with weathered bonny light crude oil (WBLCO) using biostimulation and bioaugmentation processes. A statistically significant $(p<0.0001)$ second-order regression model with a coefficient of determination $(\mathrm{R}=$ 0.9996) was ultimately obtained for removal of WBLCO. Numerical optimization process was also carried out based on desirability function to optimize the bioremediation process [34]. Further researches are ongoing to develop and improve on FD methods for minimizing the experiment number and the interactions of their input variables/parameters. This has been achieved by utilizing design experiment procedure to generate information on direct effects, interactive pair effects and effects due to curvilinear variables. Some ample studies have been done on the application of FD in bioremediation of soil contamination using bioaugmentation and biostimulation techniques as presented above. From the resources available and accessible and to the utmost best of our knowledge, there are limited or no information on the optimization of land farming procedure using FD study which plays a major role in the adequate treatment of hydrocarbon contaminated soils. In this study, FD was applied to vary the input parameters such as $\mathrm{pH}$, mass of substrate and moisture content in order to optimize them for best hydrocarbon removal. 


\section{Materials and methods}

\section{Site location}

The site selected for this project is an oil field located in Ologbo community, Ikpoba Okha Local Government Area of Edo state in Southern Nigeria. Edo state is bounded to the right by Ondo State and to the lower left by Delta (Fig. 1). Ologbo as a major community is one of the oil producing area with multiple petroleum production facilities in Niger-Delta area of Nigeria. The community houses a gas plant operated by the Nigerian National Petroleum Development Corporation (a subsidiary of Nigerian National Petroleum Corporation) and some other petroleum facilities. It lies between longitude $05^{0} 38^{\prime} 36.44^{\prime \prime} \mathrm{E}$ to $05^{\circ} 4^{\prime} 26.56^{\prime \prime} \mathrm{E}$ and latitude $06^{0} 04^{\prime} 28.17^{\prime \prime} \mathrm{N}$ to $06^{0} 04^{\prime}$ $33.79^{\prime \prime} \mathrm{N}$. It is about $32 \mathrm{~km}$ away from the southwestern part of Benin-City and over $30 \mathrm{~km}$ from Nigeria National Petroleum Development Corporation access road, which is off Benin-Sapele highway. Within this location, crude oil spillage is frequent resulting from vandalism and sabotaging of oil pipes and equipment by militants and oil pilferers, thus leaving the land degraded and contaminated. Figures 1 and 2 give the location map of the study area and one of the contaminated spots in the study area, respectively.

\section{Preliminary investigation and TPHs quantification procedure}

As a vital step towards a successful remediation process, reconnaissance survey was carried out on the contaminated site in order to minimize challenges during sample collection. A calibrated standard auger was used to collect samples at surficial depth not exceeding $30 \mathrm{~cm}$, the samples were sun dried and homogenized (using mortar and pestle) before sieving through a $4 \mathrm{~mm}$ sieve. The homogenized samples were store in polythene bags at room temperature to prevent moisturizing. The soil samples were characterized so as to determine its physical, chemical and microbes' constituents using British Standards BS 5930 (Table 1). The constituents of the soil are seen to fall below the recommended nutrients required for effective biodegradation process. Therefore, NPK fertilizer in ratio 20:10:10 and cow dung was added as additives to complement these nutriments for the remediation procedure. These fertilizers (organic and inorganic) used, have high nitrogen content which makes them suitable for remediation operations. Their compositions are shown in Table 2. Fresh samples from the contaminated site were taken to the laboratory for residual TPH quantification in accordance with USEPA [35] and ASTM [36]. TPHs were extracted from the samples by drying and passing them through a $4 \mathrm{~mm}$ sieve aperture size. The samples were placed in $40 \mathrm{~mL}$ centrifuge bottle with $25 \mathrm{~mL}$ of chloroform added. The samples were tightly closed and kept well in a sonicator bath for $60 \mathrm{~min}$. During the process of extraction, iced deionized water was continuously added to maintain a temperature below $40{ }^{\circ} \mathrm{C}$. On completion of extraction, samples were subjected again to centrifugal force for $11 \mathrm{~min}$ at $3000 \mathrm{rpm}$. The resultant extract was then placed in an Erlenmeyers flask where it was dried to achieve a specific weight. Bathing was done at $65^{\circ} \mathrm{C}$ to evaporate volatile chloroform and the extract shows an average

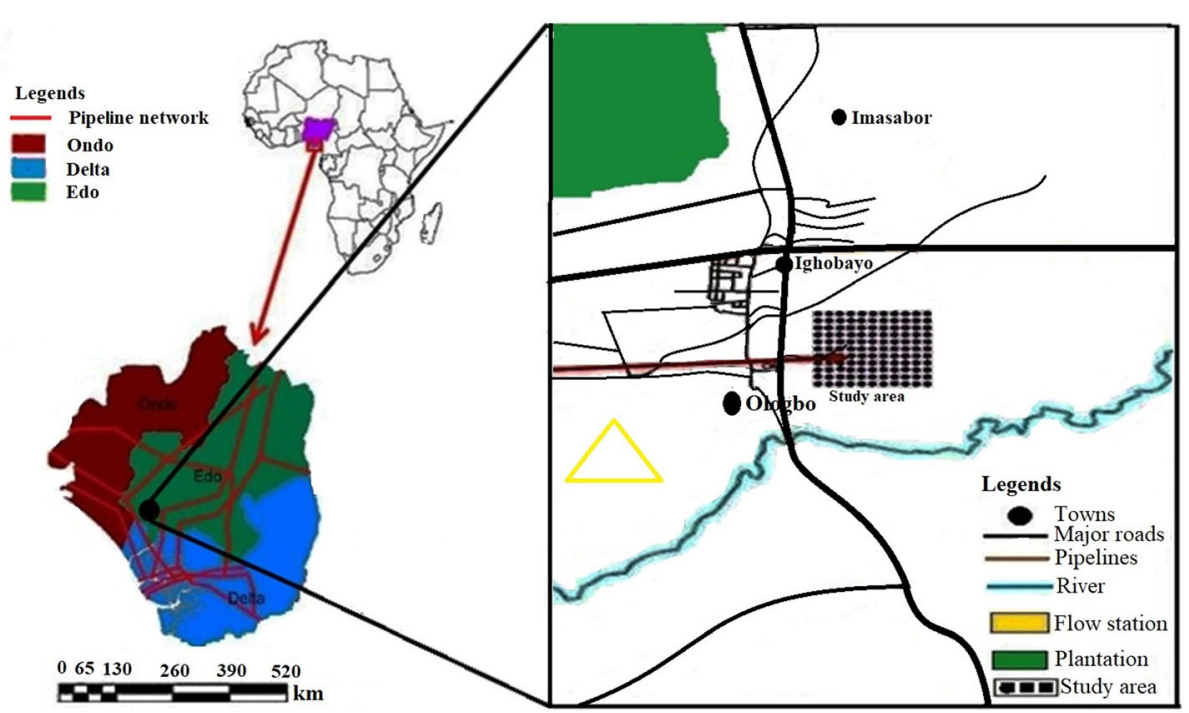

Fig. 1 Map of project location 


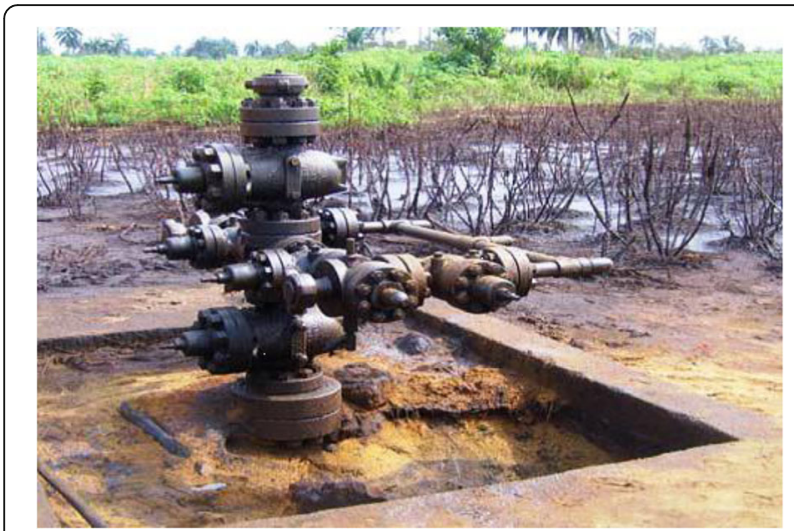

Fig. 2 Contaminated area in the study location

contamination concentration of $5000 \mathrm{mg} \mathrm{kg}^{-1}$. This is equivalent to intervention level according to USEPA, hence the need to remediate the contaminated soil.

\section{Experimental design and procedure}

In the initiation of the treatment, $100 \mathrm{~kg}$ of sieve samples were placed in twenty buckets and labeled based on the treatment to be accommodated in the setup in accordance with USEPA [35] and ASTM [36]. The choice of input variables, range of variables and duration of the experiment as stipulated in the USEPA procedure were adopted for this study. Four major input variables were selected namely $\mathrm{pH}$, moisture content, mass of substrate and turning rate and were varied in each of the buckets. Substrate used was cow dung and NPK fertilizer, with its application ranged from 0.6 to $1 \mathrm{~kg}$. In every application, mass of substrate constitutes $50 \%$ of cow dung and $50 \%$

Table 1 Physical and chemical properties of the soil used

\begin{tabular}{ll}
\hline Properties & Value \\
\hline $\mathrm{pH}(1: 1$ soil-water $)$ & 5.72 \\
Organic carbon $\left(\mathrm{g} \mathrm{kg}^{-1}\right)$ & 47.8 \\
Nitrogen $\left(\mathrm{mg} \mathrm{kg}^{-1}\right)$ & 2.83 \\
Phosphorus $\left(\mathrm{mg} \mathrm{kg}^{-1}\right)$ & 4.73 \\
Exchangeable cations & \\
$\mathrm{Ca}^{2+}\left(\mathrm{mg} \mathrm{kg}^{-1}\right)$ & 802 \\
$\mathrm{Mg}^{2+}\left(\mathrm{mg} \mathrm{kg}^{-1}\right)$ & 784 \\
$\mathrm{Na}^{+}\left(\mathrm{mg} \mathrm{kg}^{-1}\right)$ & 952 \\
$\mathrm{~K}^{-}$(mg kg & \\
Gradation analysis & 2070 \\
Sand (\%) & \\
Silt (\%) & 79.4 \\
Clay (\%) & 14.5 \\
Textural class & 6.1 \\
Specific gravity & Well graded Silt with organic content \\
\hline
\end{tabular}

Table 2 Properties of NPK fertilizer and cow dung used

\begin{tabular}{lll}
\hline Parameters & Cow dung & NPK fertilizer \\
\hline pH & 8.27 & 9.62 \\
Organic carbon (\%) & 14.36 & 8.06 \\
Total nitrogen (\%) & 40.65 & 58.40 \\
Phosphate $\left(\mathrm{mg} \mathrm{kg}^{-1}\right)$ & 23.68 & 26.07 \\
Potassium $\left(\mathrm{mg} \mathrm{kg}^{-1}\right)$ & 17.49 & 7.83 \\
Magnesium $\left(\mathrm{mg} \mathrm{kg}^{-1}\right)$ & 5.88 & 11.35 \\
Calcium $\left(\mathrm{mg} \mathrm{kg}^{-1}\right)$ & 1.42 & 37.55 \\
Sodium $\left(\mathrm{mg} \mathrm{kg}^{-1}\right)$ & 1.94 & 1.06 \\
\hline
\end{tabular}

of NPK fertilizer in any experimental run to make up the total mass of substrate required. The $\mathrm{pH}$ and moisture content of each experimental run was adjusted to reflect the value to be used for that particular setup. The $\mathrm{pH}$ was adjusted using slaked lime and measured using $\mathrm{pH}$ meter while the moisture content was a percentage of the weight of each experimental setup. The batch to batch variation was controlled using the range of input variables presented in Tables 3 and 4 . The sorption of hydrocarbon from the soil was carried out using laboratory examination in order to feasibly select factors controlling the biosorption process in land farming treatment. To be able to select the input variables with the highest significant contributions to the remediation process and determine their optimum values, FD of experiment was used for screening. The range and levels of the input variables used in designing the experiment is presented in Table 3. Runs 17-20 were used as control for the study and the treatment was carried out for $90 \mathrm{~d}$ after which the samples were taken from each bucket for residual TPH determination. According to USEPA [35] and ASTM [36], FD study of this nature with experimental setup of $2 n+1<100$, should have four middle values (control) with the same input variables, hence runs 17-20 were designated as control while all the input variable had the same range of values as shown in Table 4. Petroleum degrading bacteria was enumerated through Mineral Salt Agar culture following the procedures of Sepahi [37].

\section{Statistical analysis}

The data obtained from the experimental procedures were statistically analyzed using Excel (Microsoft office

Table 3 Ranges and levels of selected input variables

\begin{tabular}{lllll}
\hline S/No & Input variables & Unit & Lower level & Upper level \\
\hline 1 & $\mathrm{pH}$ & $\mathrm{Nil}$ & 6 & 10 \\
2 & Moisture content & $\%$ & 10 & 50 \\
3 & Mass of substrate & $\mathrm{kg}$ & 0.6 & 1.0 \\
4 & Turning rate & Times per week & 1 & 5 \\
\hline
\end{tabular}


Table 4 Response of TPH on factorial design of experiment used for variable screening

\begin{tabular}{|c|c|c|c|c|c|c|c|}
\hline Std & Run & Type & $\begin{array}{l}\text { Factor 1: } \\
\mathrm{pH}\end{array}$ & $\begin{array}{l}\text { Factor 2: Moisture content } \\
\text { (\%) }\end{array}$ & $\begin{array}{l}\text { Factor 3: Mass of substrate } \\
\text { (g) }\end{array}$ & $\begin{array}{l}\text { Factor 4: Turning rate } \\
\text { (Nil) }\end{array}$ & $\begin{array}{l}\text { TPH response ( } \mathrm{mg} \\
\mathrm{kg}^{-1} \text { ) }\end{array}$ \\
\hline 17 & 1 & Center & 8.0 & 30 & 0.8 & 3 & 847 \\
\hline 18 & 2 & Center & 8.0 & 30 & 0.8 & 3 & 723 \\
\hline 19 & 3 & Center & 8.0 & 30 & 0.8 & 3 & 782 \\
\hline 20 & 4 & Center & 8.0 & 30 & 0.8 & 3 & 862 \\
\hline 1 & 5 & Fact & 6.0 & 10 & 0.6 & 1 & 1346 \\
\hline 2 & 6 & Fact & 10.0 & 10 & 0.6 & 1 & 1204 \\
\hline 3 & 7 & Fact & 6.0 & 50 & 0.6 & 1 & 1183 \\
\hline 4 & 8 & Fact & 10.0 & 50 & 0.6 & 1 & 1048 \\
\hline 5 & 9 & Fact & 6.0 & 10 & 1 & 1 & 1248 \\
\hline 6 & 10 & Fact & 10.0 & 10 & 1 & 1 & 1344 \\
\hline 7 & 11 & Fact & 6.0 & 50 & 1 & 1 & 1394 \\
\hline 8 & 12 & Fact & 10.0 & 50 & 1 & 1 & 1304 \\
\hline 9 & 13 & Fact & 6.0 & 10 & 0.6 & 5 & 900 \\
\hline 10 & 14 & Fact & 10.0 & 10 & 0.6 & 5 & 630 \\
\hline 11 & 15 & Fact & 6.0 & 50 & 0.6 & 5 & 749 \\
\hline 12 & 16 & Fact & 10.0 & 50 & 0.6 & 5 & 490 \\
\hline 13 & 17 & Fact & 6.0 & 10 & 1 & 5 & 675 \\
\hline 14 & 18 & Fact & 10.0 & 10 & 1 & 5 & 450 \\
\hline 15 & 19 & Fact & 6.0 & 50 & 1 & 5 & 679 \\
\hline 16 & 20 & Fact & 10.0 & 50 & 1 & 5 & 573 \\
\hline
\end{tabular}

product version 16), Design-expert and STATISTICA software. The suitability of the FD to screen the variables was carried out by computing the standard error, correlation matrix of regression coefficient and model leverages. Analysis of variance (ANOVA) and goodness of fit were also computed to validate the model significance. The major effects of the four-treatment variable as well as the interactions were interpreted jointly. In every $2^{2}$ factorial designs, the F-tests is enough to reveal the interrelation in combined treatment procedures. It also tells the relationship between all the variables concentrations in the treatment parameters. The result reveals the main variable with the largest effect in the four combined parameters by comparing the means. The F-test procedures employed are shown in Eqs. (1), (2) and (3) respectively.

$$
\begin{gathered}
F_{\text {presentation }}=\frac{S S_{\text {presentation }} / d f_{\text {presentation }}}{S S_{\text {error }} / d f_{\text {error }}} \\
F_{\text {difficulty }}=\frac{S S_{\text {difficulty }} / d f_{\text {difficulty }}}{S S_{\text {error }} / d f_{\text {error }}} \\
F_{\text {interaction }}=\frac{S S_{\text {interaction }} / d f_{\text {interaction }}}{S S_{\text {error }} / d f_{\text {error }}}
\end{gathered}
$$

where $F_{\text {presentation }}=$ main effect due to presentation, $F_{\text {diffi- }}$ culty $=$ main effect due to difficulty, and $F_{\text {interaction }}=$ main effects due to interaction.

\section{Results and discussion TPH biodegradation}

The degradation for standard run 17-20 which serve as control for the study was similar having the same combined variables. TPH concentration degraded from 5000 $\mathrm{mg} \mathrm{kg}^{-1}$ to between 722 and $862 \mathrm{mg} \mathrm{kg}^{-1}$ in 90 days duration while maintaining $3 \mathrm{~d} \mathrm{wk}^{-1}$ turning rate. Standard runs $3,4,7,8,11,12,15$, and 16; with moisture content of $50 \%$ the set-ups had hydrocarbon content floating on the surface. This made the admix semifluid in nature and easy to turn using hand trowel. When turning rate is effective and properly practice, the hydrocarbon contaminants becoming exposed to degrading agents and are therefore either degraded or mineralized [16]. This is attributed to the over $80 \% \mathrm{TPH}$ reduction recorded in standard run 16 after $90 \mathrm{~d}$ treatment.

Substrate addition also enhanced TPH degradation as it serves as energizer for the microbes. This served mainly as catalyst in microbial reproduction processes and consequent consumption of the TPH contaminants. 
Although higher concentration of substrate does not guarantee high TPH degradation, but when suitably combined with other parameters such as turning rate, high $\mathrm{pH}$ value and average moisture content; then a better degradation result can be obtained [27]. As fertilizer application on crude oil contaminated site was well systemic and well calculated, TPH degradation result was less than $40 \%$, this was mainly due to the low moisture content and high acidic values of the treated samples. Nwilo and Badejo [11] had similar results from their study in which NPK fertilizer was used in the treatment of soil collected from a spill site. TPH degradation was faster in samples with lower moisture content than samples with higher moisture content. The $\mathrm{pH}$ of the contaminated soil samples before treatment ranged from 2 to 5 . An increase in $\mathrm{pH}$ values was observed as the treatment progress into day 15 to 70 , the $\mathrm{pH}$ value ranged from 5.7 to 7.1 (neutral). The addition of fertilizer to hydrocarbon polluted soil samples had a catalyst effect on the treatment and the $\mathrm{pH}$ value increase from acidic range of 2 to neutral range of 6.8 . The substrate applied caused an increase in the total nitrogenous content of the soil but as the treatment days increased from day $50-60$, the nitrogen content decreased gradually. This could be linked to the soil bacterial consuming the nitrogen for the hydrocarbon degradation, thus reducing the available nitrogen as treatment time increases [9]. This process utilizes biochemical reduction and it is initiated by denitrifying bacterial in the soil [11]. In all the factorial setups for the hydrocarbon contamination treatment, there was significant TPH degradation and the bacterial population in all the setups increased exponentially. The petroleum degrading bacteria increased from $1.8 \mathrm{E}+01$ to $3.6 \mathrm{E}+08 \mathrm{cfu} \mathrm{g}^{-1}$ during the treatment period. This increase confirms the loss of nitrogen which usually accompany degradation procedures $[11,17]$. This increment in petroleum degrading bacteria is in tandem with the findings of Oluwatuyi et al. [12] and Okonofua et al. [13]. FD analysis of results was then employed to determine the variable with the most significant contribution in the TPH degradation procedure.

\section{FD of experiment}

The response of TPHs on FD of experiment, used for variable screening hydrocarbon contaminant concentration of $5000 \mathrm{mg} \mathrm{kg}^{-1}$ within a period of $90 \mathrm{~d}$ is presented in Table 4. The minimum value of TPH is given as 450 $\mathrm{mg} \mathrm{kg}^{-1}$ while the maximum value is $1393 \mathrm{mg} \mathrm{kg}^{-1}$. The calculated mean value is $921 \mathrm{mg} \mathrm{kg}^{-1}$ with the standard deviation of $302 \mathrm{mg} \mathrm{kg}^{-1}$. In assessing the worthiness of FD in screening the input variables based on their fundamental and important contributions, model standard error analysis was used based on Montgomery [38]. Presented in Table 5 are the computed standard errors for
Table 5 Result of computed standard errors

\begin{tabular}{lllllll}
\hline \multicolumn{7}{l}{ Powered at 5\% level for effect of } \\
\hline Term & Std err $^{\text {a }}$ & VIF & $\begin{array}{l}\text { Ri- } \\
\text { squared }\end{array}$ & $\begin{array}{l}\mathbf{0 . 5} \text { Std } \\
\text { dev. }\end{array}$ & $\begin{array}{l}\text { 1 Std } \\
\text { dev. }\end{array}$ & $\begin{array}{l}\text { 2 Std } \\
\text { dev. }\end{array}$ \\
\hline A & 0.25 & 1.00 & 0.000 & 14.6 & 43.91 & 94.4 \\
B & 0.25 & 1.00 & 0.000 & 14.6 & 43.91 & 94.4 \\
C & 0.25 & 1.00 & 0.000 & 14.6 & 43.91 & 94.4 \\
D & 0.25 & 1.00 & 0.000 & 14.6 & 43.91 & 94.4 \\
AB & 0.25 & 1.00 & 0.000 & 14.6 & 43.91 & 94.4 \\
AC & 0.25 & 1.00 & 0.000 & 14.6 & 43.91 & 94.4 \\
AD & 0.25 & 1.00 & 0.000 & 14.6 & 43.91 & 94.4 \\
BC & 0.25 & 1.00 & 0.000 & 14.6 & 43.91 & 94.4 \\
BD & 0.25 & 1.00 & 0.000 & 14.6 & 43.91 & 94.4 \\
CD & 0.25 & 1.00 & 0.000 & 14.6 & 43.91 & 94.4 \\
\hline
\end{tabular}

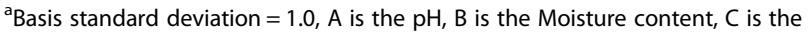
Mass of substrate, $D$ is the Turning rate, VIF is the Variance Inflation Factor

the chosen response. From the result, a low model standard error of 0.25 was achieved for both the individual and combine terms and effects. According to Jasmine and Mukherji [33], standard errors must be akin within a coefficient and the lower the value is, the better. Similarly, the error values were lower than the model basic standard deviation (SD) of 1.0 suggesting that the FD was perfect for the screening process. To demonstrate for multicollinearity, the variance inflation factor (VIF) of the analysis was obtained all through as 1.0 representing a superb outcome as a perfect VIF should give 1.0. VIFs closer to 10 or greater are usually cause for concern, and this signifies that coefficients are basely calculated due to multicollinearity [39].

Furthermore, the Ri-squared values also gives zero which perfectly match an ideal Ri-square as high Risquared especially values above 1.0 shows that design terms are correlated utimately resulting to poor models. Table 6 presents the correlation matrix of the regression coefficient. It can be seen that, off diagonal matrix, the lower values obtained point out the fact that the model is well fitted and it is strengthened enough to pilot the design space thus adequately optimizing the chosen response variable. Also, the model leveages were computed in order to better understand the influencial effect of individual design points on the model's predicted value. According to Meloun and Militky [40], leverage point indicates the extent of influence of an individual design point on the model's predicted values and it usually varies from 0 to 1 . A leverage of 1 indicates that, the predicted value at a specific case will perfectly equal the observed value of the experiment, making the residual to be zero. The addition of leverage values in all cases equals the number of coefficients fit by the model, and the ultimate leverage an experiment can have is determined by $1 / \mathrm{m}$, with $\mathrm{m}$ being the number of rounds the 
Table 6 Correlation matrix of regression coefficients

\begin{tabular}{|c|c|c|c|c|c|c|c|}
\hline \multicolumn{8}{|c|}{ Correlation matrix of regression coefficients } \\
\hline & Intercept & A & B & C & D & $A B$ & AC \\
\hline Intercept & 1.000 & & & & & & \\
\hline A & -0.000 & 1.000 & & & & & \\
\hline B & -0.000 & -0.000 & 1.000 & & & & \\
\hline C & -0.000 & -0.000 & -0.000 & 1.000 & & & \\
\hline D & -0.000 & -0.000 & -0.000 & -0.000 & 1.000 & & \\
\hline$A B$ & -0.000 & -0.000 & -0.000 & -0.000 & $\begin{array}{l}- \\
0.000\end{array}$ & 1.000 & \\
\hline$A C$ & -0.000 & -0.000 & $\overline{0.000}$ & $\overline{0 .}$ & $-\overline{0.000}$ & -0.000 & 1.000 \\
\hline$A D$ & -0.000 & $\begin{array}{l}- \\
0.000\end{array}$ & $\begin{array}{l}- \\
0.000\end{array}$ & $\begin{array}{l}- \\
0.000\end{array}$ & $\begin{array}{l}- \\
0.000\end{array}$ & -0.000 & -0.000 \\
\hline BC & -0.000 & $\begin{array}{l}- \\
0.000\end{array}$ & $\begin{array}{l}- \\
0.000\end{array}$ & $\begin{array}{l}- \\
0.000\end{array}$ & $\begin{array}{l}- \\
0.000\end{array}$ & -0.000 & -0.000 \\
\hline $\mathrm{BD}$ & -0.000 & - & $\overline{-}-000$ & -0.000 & $\begin{array}{l}- \\
0.000\end{array}$ & -0.000 & -0.000 \\
\hline$C D$ & -0.000 & $\begin{array}{l}- \\
0.000\end{array}$ & -0.000 & $\begin{array}{l}- \\
0.000\end{array}$ & -0.000 & -0.000 & -0.000 \\
\hline
\end{tabular}

experiment was repeated. Leverage of 0.675 calculated in the factorial point indicates that, there is closeness between the predicted values and the experimental values. Hence, less or low residual value approves the sufficiency of the model.

\section{Strength assessment of factorial model}

To assess the strength of the factorial model towards an effective screening and optimization of the input variables, based on their significant contributions, one-way ANOVA was done for the response variable (Table 7). This was used to examine if the model is significant or not and to also measure the important contributions of individual variable. From the analysis in Table 7, the Model F-value of 56 connotes that the model is significant owing to the fact that there is only $0.01 \%$ probability that a "Model F-Value" with high value could occur due to noise. When the values of "Prob $>$ F" are $<0.05$, it indicate that the model terms are significant while values $>0.1$ indicate the model terms are not significant [41].

Therefore, the terms A, D, AD, BC and $\mathrm{CD}$ are all significant model terms. Also, 22 from the "Curvature Fvalue" means that there exist significant curvature in the design space. This is mostly estimated by the difference between the average of the factorial points and that of the center points, and there is just $0.15 \%$ chance that a "Curvature F-value" with high value could occur as noise. Furthermore, 0.60 from the "Lack of Fit F-value" connotes that, it is not significant when compared with the pure error but on the other hand, there is a $71 \%$
Table 7 Analysis of variance table for input variable screening

\begin{tabular}{|c|c|c|c|c|c|c|}
\hline \multicolumn{7}{|c|}{ ANOVA for selected factorial model } \\
\hline \multicolumn{7}{|c|}{ Analysis of variance table (partial sum of squares type-III) } \\
\hline Source & $\begin{array}{l}\text { Sum of } \\
\text { squares }\end{array}$ & df & $\begin{array}{l}\text { Mean } \\
\text { square }\end{array}$ & F-Value & $\begin{array}{l}\text { P-Value } \\
\text { Prob }>\mathrm{F}\end{array}$ & Comments \\
\hline Model & $1.736 \mathrm{E}+0.06$ & 10 & $1.736 \mathrm{E}+005$ & 56.24 & $<0.0001$ & Significant \\
\hline A-pH & 79,778 & 1 & 79,778 & 25.85 & 0.0009 & \\
\hline $\begin{array}{l}\text { B-Moisture } \\
\text { content }\end{array}$ & 8845 & 1 & 8845 & 2.87 & 0.1289 & \\
\hline $\begin{array}{l}\text { C-Mass of } \\
\text { substrate }\end{array}$ & 842 & 1 & 843 & 0.27 & 0.6155 & \\
\hline D-Turning rate & $1.515 E+006$ & 1 & $1.515 E+006$ & 490.76 & $<0.0001$ & \\
\hline$A B$ & 150 & 1 & 150 & 0.048 & 0.8312 & \\
\hline$A C$ & 14,629 & 1 & 14,629 & 4.74 & 0.0612 & \\
\hline$A D$ & 21,650 & 1 & 21,650 & 7.01 & 0.0293 & \\
\hline$B C$ & 44,310 & 1 & 44,310 & 14.35 & 0.0053 & \\
\hline $\mathrm{BD}$ & 145 & 1 & 145 & 0.047 & 0.8339 & \\
\hline$C D$ & 50,623 & 1 & 50,623 & 16.40 & 0.0037 & \\
\hline Curvature & 69,348 & 1 & 69,348 & 22.47 & 0.0015 & Significant \\
\hline Residual & 24,694 & 8 & 3067 & & & \\
\hline Lack of fit & 12,376 & 5 & 2475 & 0.60 & 0.7107 & $\begin{array}{l}\text { Non- } \\
\text { significant }\end{array}$ \\
\hline Pure error & 12,318 & 3 & 4106 & & & \\
\hline
\end{tabular}

probability that a "Lack of Fit F-value" could occur due to noise. In Table 8, the goodness of fit statistics was used to formalize the sufficiency of the factorial model regarding its potential to screen the input variables based on their significant contribution. From the statistical analysis, the "Predicted R-Squared" value of 0.9188 is in logical agreement with the "Adj R-Squared" value of 0.9684. According to Singh et al. [42], obtaining an adequate precision shows an adequate signal to noise ratio $>4$ as desirable. Thus, the computed ratio of 20 as shown in Table 8 connotes an adequate signal. This model outcome therefore shows that it can be used to pilot the design space and properly screen the input variables while also determine their optimum value.

\section{Input parameters and generated equation}

The significant contributions of each input variables were determined using pareto chart. Pareto chart is a graphical presentation of input variables in order of their

Table 8 Goodness of fit statistics for validating model significance

\begin{tabular}{lllll}
\hline S/No & ANOVA parameters & Value & ANOVA Parameters & Value \\
\hline 1 & Std Dev. & 56 & R-Squared & 0.9860 \\
2 & Mean & 921 & Adj. R-Squared & 0.9684 \\
3 & C.V. (\%) & 6 & Pred. R-Squared & 0.9188 \\
4 & PRESS & $1.49 \mathrm{E}+005$ & Adeq. Precision & 20 \\
\hline
\end{tabular}

Note: The 'Pred. R-Squared' of 0.9188 is in reasonable agreement with the 'Adj. R-Squared' of 0.9684 . PRESS Prediction error sum of squares 


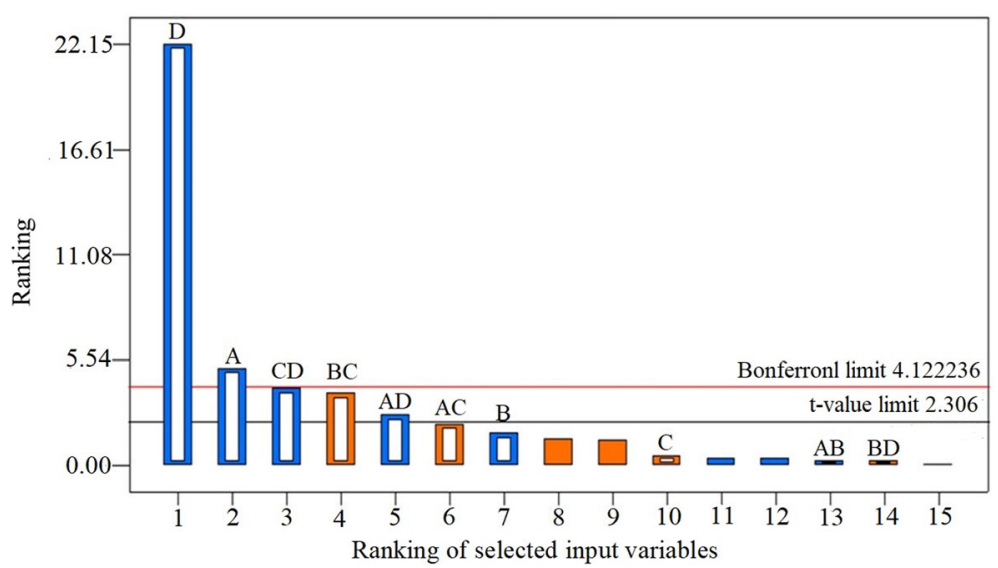

Fig. 3 Pareto chart showing the ranking of the selected input variables

ranking. Statistical tool was used to generate Pareto's chart (Fig. 3) for the selected input variables. The result shows that the variables contributed to the hydrocarbon degradation in varying proportion with turning rate, $\mathrm{pH}$, moisture content and mass of substrate all contributing 83, $4.36,0.48$ and $0.046 \%$ respectively. Furthermore, the most fitting equation which depicts both the combine interactions and individual effects of the significant input variables $(\mathrm{pH}$, moisture content, mass of substrate and turning rate) against the mesured response (TPH) is provided based on the coded variables and the actual factors which are shown in Eqs. (4) and (5). Either of these two equations can be used in the estimation of the predicted TPH values which is shown in column 3 of Table 9. The predicted TPH values are then compared with the measured values to obtain the residual and the cook's distance shown in columns 4 and 9 in Table 9. In FD study, only terms without coefficients (zero coefficient)

Table 9 Diagnostics case statistics report of observed and predicted TPH

\begin{tabular}{|c|c|c|c|c|c|c|c|c|c|}
\hline $\begin{array}{l}\text { Standard } \\
\text { order }\end{array}$ & $\begin{array}{l}\text { Actual } \\
\text { value }\end{array}$ & $\begin{array}{l}\text { Predicted } \\
\text { value }\end{array}$ & Residual & Leverage & $\begin{array}{l}\text { Internally } \\
\text { studentized residual }\end{array}$ & $\begin{array}{l}\text { Externally } \\
\text { studentized residual }\end{array}$ & $\begin{array}{l}\text { Influence on } \\
\text { fitted value }\end{array}$ & $\begin{array}{l}\text { Cook's } \\
\text { distance }\end{array}$ & $\begin{array}{l}\text { Run } \\
\text { order }\end{array}$ \\
\hline 1 & 1346 & 1335 & 10.37 & 0.688 & 0.334 & 0.315 & 0.467 & 0.020 & 5 \\
\hline 2 & 1204 & 1213 & -9.51 & 0.688 & -0.306 & -0.288 & -0.427 & 0.017 & 6 \\
\hline 3 & 1183 & 1183 & 0.32 & 0.688 & 0.010 & 0.010 & 0.014 & 0.000 & 7 \\
\hline 4 & 1048 & 1049 & -1.18 & 0.688 & -0.038 & -0.036 & -0.053 & 0.000 & 8 \\
\hline 5 & 1248 & 1297 & -48.89 & 0.688 & -1.574 & -1.773 & -2.63 & 0.454 & 9 \\
\hline 6 & 1345 & 1296 & 48.03 & 0.688 & 1.546 & 1.728 & 2.56 & 0.438 & 10 \\
\hline 7 & 1393 & 1355 & 38.03 & 0.688 & 1.230 & 1.278 & 1.895 & 0.277 & 11 \\
\hline 8 & 1304 & 1342 & -37.34 & 0.688 & -1.202 & -1.242 & -1.843 & 0.265 & 12 \\
\hline 9 & 900 & 900 & 0.13 & 0.688 & 0.004 & 0.004 & 0.006 & 0.000 & 13 \\
\hline 10 & 630 & 631 & -0.99 & 0.688 & -0.032 & -0.030 & -0.044 & 0.000 & 14 \\
\hline 11 & 749 & 760 & -10.82 & 0.688 & -0.348 & 0.328 & -0.487 & 0.022 & 15 \\
\hline 12 & 490 & 478 & 11.68 & 0.688 & 0.376 & 0.355 & 0.527 & 0.026 & 16 \\
\hline 13 & 675 & 636 & 38.40 & 0.688 & 1.236 & 1.286 & 1.907 & 0.280 & 17 \\
\hline 14 & 450.43 & 488 & -37.53 & 0.688 & -1.208 & -1.250 & -1.854 & 0.268 & 18 \\
\hline 15 & 679 & 707 & -27.71 & 0.688 & -0.892 & -0.879 & -1.304 & 0.146 & 19 \\
\hline 16 & 573 & 546 & 26.84 & 0.688 & 0.864 & 0.849 & 1.259 & 0.137 & 20 \\
\hline 17 & 847 & 804 & 43.59 & 0.250 & 0.906 & 0.895 & 0.517 & 0.023 & 1 \\
\hline 18 & 723 & 804 & -80.74 & 0.250 & -1.678 & -1.950 & -1.126 & 0.078 & 2 \\
\hline 19 & 782 & 804 & -21.49 & 0.250 & -0.447 & -0.423 & -0.244 & 0.006 & 3 \\
\hline 20 & 862 & 804 & 58.63 & 0.250 & 1.219 & 1.263 & 0.729 & 0.041 & 4 \\
\hline
\end{tabular}




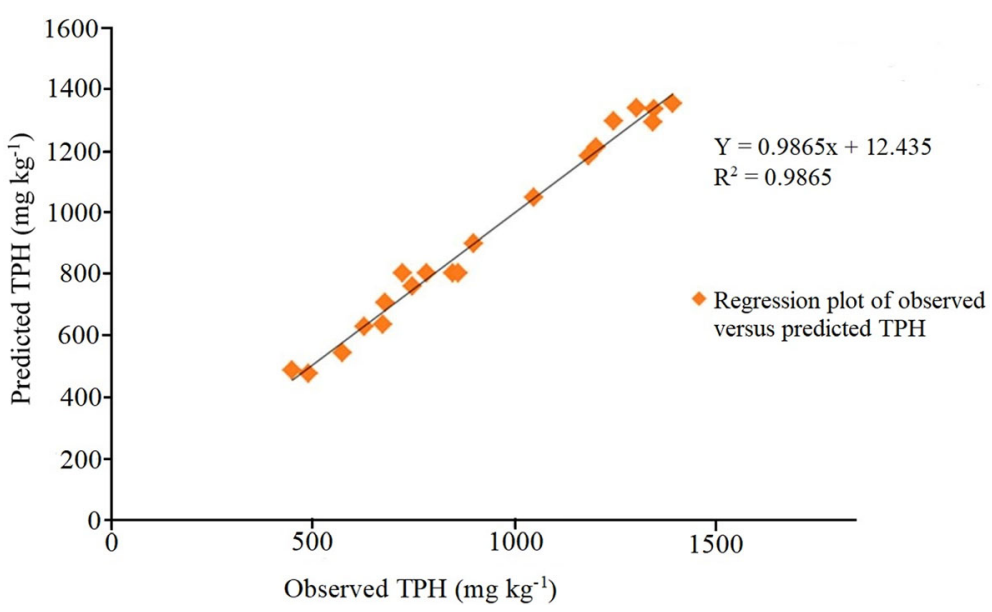

Fig. 4 Reliability plot of observed versus predicted TPH

are left out in TPH evaluation using either coded or actual factors, hence the inclusion of $\mathrm{AB}$ and $\mathrm{BD}$.

$$
\begin{aligned}
\mathrm{TPH}= & 950.88-70.61 \mathrm{~A}-23.51 \mathrm{~B} \\
& +7.26 \mathrm{C}-307.70 \mathrm{D}-3.06 \mathrm{AB} \\
& +30.24 \mathrm{AC}-36.78 \mathrm{AD}+52.63 \mathrm{BC} \\
& +3.01 \mathrm{BD}-56.25 \mathrm{CD} \\
\mathrm{TPH}= & 1930.89-65.90 \mathrm{~A}-11.32 \mathrm{~B}-541.29 \mathrm{C} \\
& +29.96 \mathrm{D}-0.08 \mathrm{AB} \\
& +75.59 \mathrm{AC}-9.20 \mathrm{AD}+13.16 \mathrm{BC} \\
& +0.08 \mathrm{BD}-140.62 \mathrm{CD}
\end{aligned}
$$

The symptomatic case statistics show the observed values of the response covariant (TPH) against the predicted values as shown in Table 9. This symptomatic case statistics vividly present a clear and deep understanding into the model strength and the adequacy of the FD model.

\section{Model validation}

To further evaluate the accuracy of the prediction and established the appropriateness of FD of experiment, the observed and predicted values of TPH were presnted via a reliability plot as shown in Fig. 4. The $r^{2}=0.9865$ which represents the coefficient of determination was utilized in affirming the eligibility of the $\mathrm{FD}$ in reducing the TPH. An adequate statistical analysis output must first be used to check the satisfactoriness level of any model before its acceptance. Thus, to examine the statistical properties of the FD model, the normal probability plot of studentized

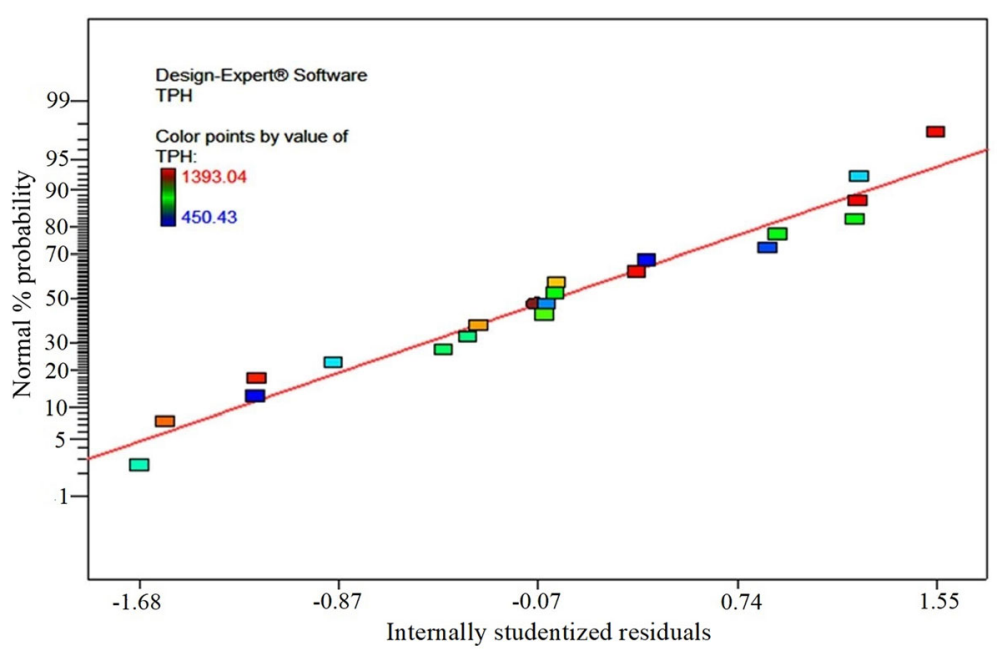

Fig. 5 Normal probability plot of studentized residuals for TPH 


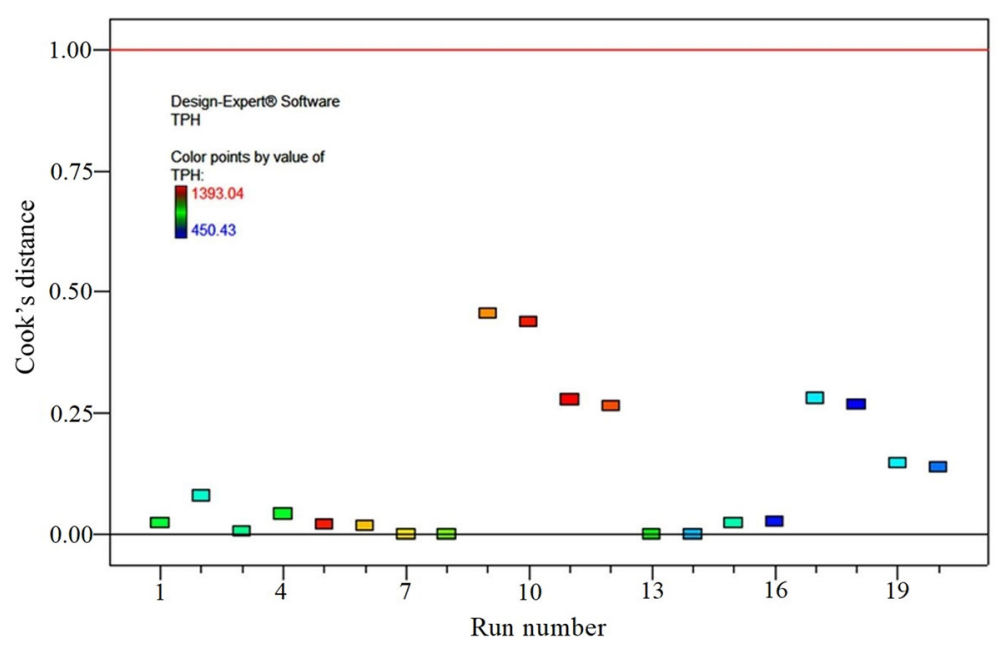

Fig. 6 Generated cook's distance for TPH

residual shown in Fig. 5 was used to evaluate the regularity of the calculated residuals. The plot of residuals which represent the standard deviation of actual values based on the predicted values was adopted to ascertain if the residuals (observed-predicted) follow a normal distribution pattern. It was depicted that, the computed residuals are normally and approximately distributed which indicates the degree of satisfaction of the developed model. Furthermore, in the analysis, to determine the availability of a possible outlier, cook's distance plot was generated (Fig. 6). This cook's distance is to measure the degree at which the regression can change if the outlier is excluded from the analysis. A particular point having a high distance value relative to the other points can possibly be an outlier and should therefore be investigated [43]. From Fig. 6, the plot shows an upper bound and lower bound of 1.00 and 0.00 . Therefore, experimental values below the lower bound $(0.00)$ or above the upper bounds (1.00) are termed as outliers which must be adequately investigated. Fortunately, the data of this analysis are free of possible outliers thus showing forth the adequacy of the experimental data. A 3D surface response plot was also provided to study the effects of combine input variables on the response (Fig. 7). It can be seen that the plot depicts the connection between the input variables $(\mathrm{pH}$ and turning rate) and the response variable (TPH) and also provides a comprehensible concept of the factorial model. In addition, the colour of the surface gets darker towards the turning rate which connotes that a higher turning rate leads to a reduction in TPH. This observation is in tandem with the work of Agarry and Ogunleye [34].

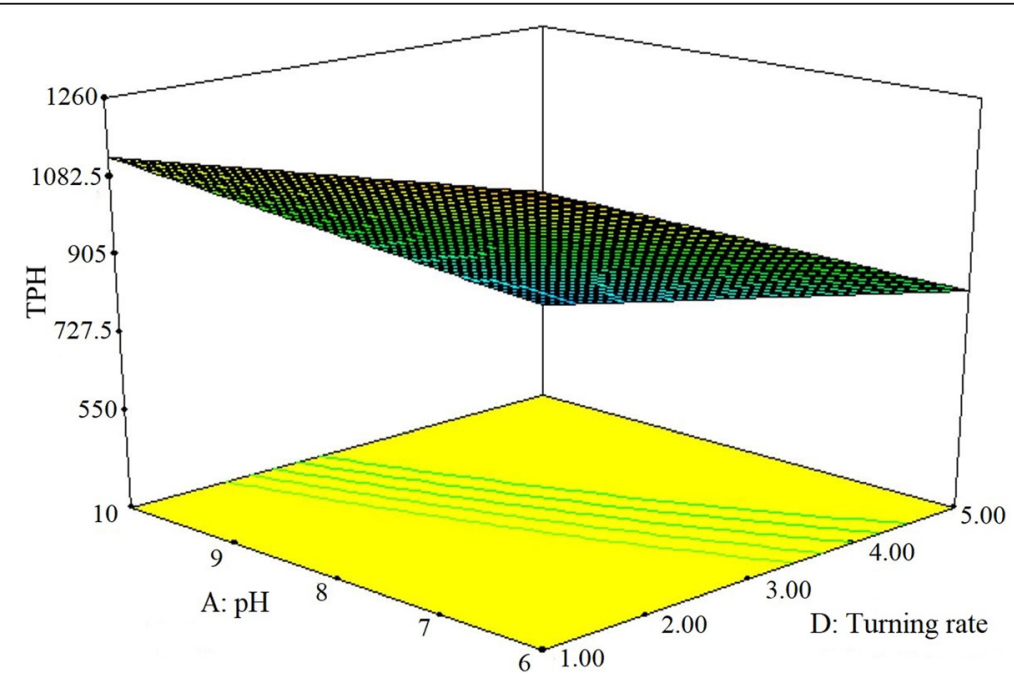

Fig. 7 Effect of $\mathrm{pH}$ and turning rate on $\mathrm{TPH}$ 
Table 10 Optimal solutions of numerical optimization model

\begin{tabular}{|c|c|c|c|c|c|c|c|}
\hline Number & $\mathrm{pH}$ & Moisture content & Mass of substrate & Turning rate & TPH & Desirability & \\
\hline 1 & 6.01 & 10.00 & 1.00 & 5.00 & 635.907 & 0.986 & Selected \\
\hline 2 & 6.00 & 17.44 & 1.00 & 4.99 & 650.986 & 0.985 & \\
\hline 3 & 6.00 & 23.73 & 1.00 & 5.00 & 660.319 & 0.984 & \\
\hline 4 & 6.00 & 24.32 & 1.00 & 5.00 & 661.415 & 0.984 & \\
\hline 5 & 6.00 & 28.81 & 1.00 & 5.00 & 669.695 & 0.984 & \\
\hline 6 & 6.00 & 30.84 & 1.00 & 5.00 & 672.851 & 0.983 & \\
\hline 7 & 6.00 & 32.26 & 1.00 & 5.00 & 675.421 & 0.983 & \\
\hline 8 & 6.00 & 31.47 & 1.00 & 4.98 & 677.410 & 0.983 & \\
\hline 9 & 6.00 & 10.00 & 0.96 & 4.91 & 679.292 & 0.983 & \\
\hline 10 & 6.00 & 37.28 & 1.00 & 5.00 & 684.185 & 0.982 & \\
\hline 11 & 6.00 & 40.14 & 1.00 & 5.00 & 689.686 & 0.982 & \\
\hline 12 & 6.00 & 39.45 & 0.99 & 5.00 & 676.788 & 0.982 & \\
\hline 13 & 6.00 & 33.53 & 1.00 & 5.00 & 698.162 & 0.981 & \\
\hline 14 & 6.00 & 45.15 & 1.00 & 5.00 & 704.886 & 0.981 & \\
\hline 15 & 6.00 & 34.21 & 1.00 & 4.84 & 707.500 & 0.981 & \\
\hline 16 & 6.00 & 41.29 & 0.93 & 5.00 & 716.346 & 0.980 & \\
\hline 17 & 6.00 & 21.70 & 0.88 & 5.00 & 720.118 & 0.979 & \\
\hline 18 & 6.00 & 10.00 & 0.87 & 5.00 & 734.523 & 0.979 & \\
\hline 19 & 6.00 & 24.54 & 0.84 & 5.00 & 735.764 & 0.978 & \\
\hline 20 & 6.00 & 50.00 & 0.77 & 5.00 & 736.972 & 0.978 & \\
\hline
\end{tabular}

\section{Numerical optimizaton}

The numerical optimization was finally done to be sure of the desirability of the absolute model. Design expert was adopted in the numerical optimization phase in order to minimize the TPH level and determine the optimum $\mathrm{pH}$, moisture content, mass of substrate and the turning rate. The numerical optimization interphase presents the objective function (Figure S1 of Supplemental Information) with production of twenty (20) optimal solutions (Table 10). From the analysis, turning rate of 5 times a week, with $\mathrm{pH}$ of 6.01 , moisture content of $10 \%$ and substrate mass of $1 \mathrm{~kg}$ will result in a minimum $\mathrm{TPH}$ value of 636 with a reliability value of $98.6 \%$. The ramp solution showing the graphical representation of the best solution (Figure S2) while the desirability chart depicting the veracity with which the model can predict the values of the chosen input variables and

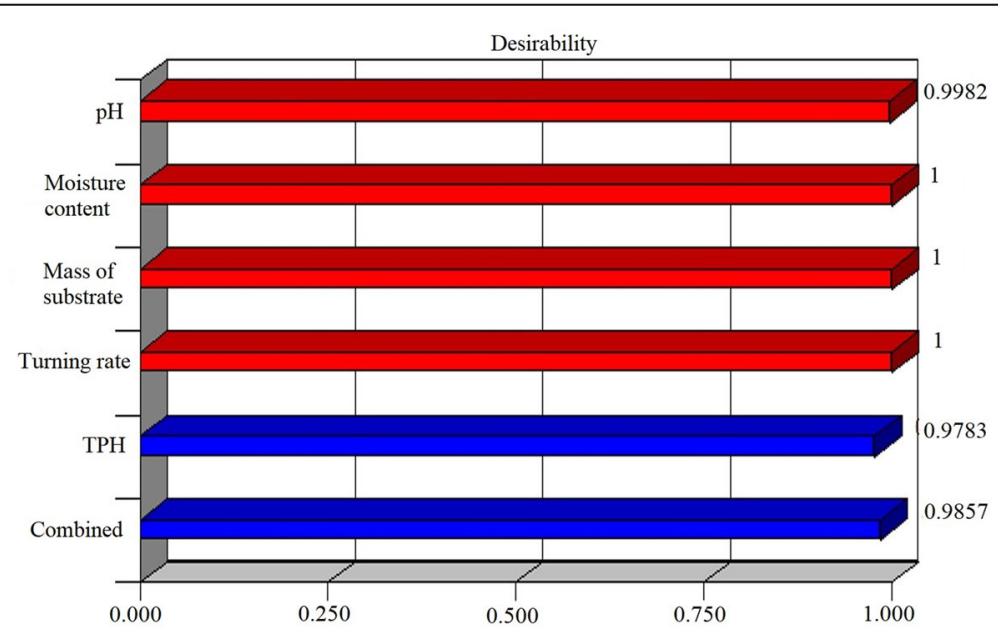

Fig. 8 Prediction accuracy of numerical optimzation 
the similar response is presented in Fig. 8. From the outcome on the chart, it can be inferred that the developed and optimized model using FD and numerical optimization method respectively, predicted the TPH by an accuracy level of $97.83 \%$.

\section{Conclusions}

This research has studied the remediation of total petroleum hydrocarbon using an environmental friendly method in order to create a clean environment. Factorial design was applied in varying the input parameters $(\mathrm{pH}$, mass of substrate, moisture content and turning) of land farming treatment in order to ascertain the optimal conditions for the procedure. The significant contributions of each input variables which are $\mathrm{pH}$, moisture content, mass of substrate and turning rate associated in the land farming treatment process revealed that, turning rate with $83 \%$ was the highest contribution while $\mathrm{pH}$, moisture content and mass of substrate had 4.36, 0.48 and $0.046 \%$ contributions, respectively. The numerical optimization done to be sure of the desirability of the absolute model revealed that with initial contamination concentration of $5000 \mathrm{mg} \mathrm{kg}^{-1}$; turning rate of 5 times weekly, $\mathrm{pH}$ of 6.01 , moisture content of $10 \%$ and substrate mass of $1 \mathrm{~kg}$ will achieve a minimum TPH value of $636 \mathrm{mg} \mathrm{kg}^{-1}$ with $98.6 \%$ reliability thus validating the factorial experimental design established for this study.

\section{Supplementary Information}

The online version contains supplementary material available at https://doi. org/10.1186/s42834-021-00079-7

Additional file 1: Figure S1. Interphase of numerical optimization model for minimizing total petroleum hydrocarbon. Figure S2. Ramp solution of numerical optimization

\section{Acknowledgments}

The authors express gratitude to the Federal Government of Nigeria for providing funding for this research which was undertaken at the Federal University of Technology Akure through the Tertiary Education Fund (TETfund) with Grant No REG/SSA/P.13735/75.

\section{Authors' contributions}

OES conceived and investigated the experiment, and was also a major contributor in writing the manuscript. LKH analyzed data and interpreted the result, and was also a major contributor in writing of the manuscript. AE supervised the research and also edit the manuscript. All authors read and approved the final manuscript."

\section{Funding}

This research was funded by the Tertiary Education Fund (an organization under the auspices of the Federal Government of Nigeria) with Grant No REG/SSA/P.13735/75

Availability of data and materials Not applicable.

\section{Competing interests}

The authors declare that they have no competing interests.

\section{Author details}

${ }^{1}$ Department of Geomatics, University of Benin, Benin City 300283, Nigeria. ${ }^{2}$ Department of Civil and Environmental Engineering, Federal University of Technology, Akure 340252, Nigeria. ${ }^{3}$ Institute of Urban Environment, Chinese Academy of Sciences, Xiamen 361021, China. ${ }^{4}$ Department of Civil and Environmental Engineering, Delta State University, Abraka 330106, Nigeria.

Received: 30 July 2020 Accepted: 22 January 2021

Published online: 05 February 2021

References

1. IEA. 2012 Key World Energy Statistics. Paris: International Energy Agency; 2012

2. Ajiboye AV, Lasisi KH, Babatola JO. Evaluation of the effect of sodium hydroxide solution on biogas yield of anaerobic digestion of poultry waste and the digestate. Int J Energ Water Res. 2018;2:23-31.

3. Gharaee A, Khosravi-Nikou MR, Anvaripour B. Hydrocarbon contaminated soil remediation: a comparison between Fenton, sono-Fenton, photoFenton and sono-photo-Fenton processes. J Ind Eng Chem. 2019;79:181-93.

4. Zabbey N, Uyi H. Community responses of intertidal soft-bottom macrozoobenthos to oil pollution in a tropical mangrove ecosystem, Niger Delta, Nigeria. Mar Pollut Bull 2014;82:167-74.

5. Sam K, Coulon F, Prpich G. Management of petroleum hydrocarbon contaminated sites in Nigeria: current challenges and future direction. Land Use Policy. 2017;64:133-44.

6. Ambituuni A, Amezaga J, Emeseh E. Analysis of safety and environmental regulations for downstream petroleum industry operations in Nigeria: problems and prospects. Environ Dev. 2014;9:43-60.

7. Konne BR. Inadequate monitoring and enforcement in the Nigerian oil industry: the case of shell and Ogoniland. Cornell Int Law J. 2014;47:181204.

8. Ite AE, Ibok UJ, Ite MU, Petters SW. Petroleum exploration and production: past and present environmental issues in the Nigeria's Niger Delta. Ame J Environ Prot. 2013;1:78-90.

9. Linden O, Palsson J. Oil contamination in Ogoniland, Niger Delta. Ambio. 2013:42:685-701.

10. UNEP. Environmental assessment of Ogoniland. Nairobi: United Nations Environment Programme; 2011

11. Nwilo PC, Badejo OT. Impacts and management of oil spill pollution along the Nigerian coastal areas. In: Administering marine spaces: international issues. Copenhagen: International Federation of Surveyors; 2006. p. 119-33.

12. Oluwatuyi OE, Ajibade FO, Ajibade TF, Adelodun B, Olowoselu AS, Adewumi $J R$, et al. Total concentration, contamination status and distribution of elements in a Nigerian State dumpsites soil. Environ Sustain Indic. 2020;5: 100021

13. Okonofua ES, Babatola JO, Ojuri OO. Evaluation of total petroleum hydrocarbon content in crude oil exploration field. J Niger Assoc Math Phys. 2018;47:229-34

14. Lin QX, Mendelssohn IA. Potential of restoration and phytoremediation with Juncus roemerianus for diesel-contaminated coastal wetlands. Ecol Eng. 2009:35:85-91.

15. Gomez F, Sartaj M. Field scale ex-situ bioremediation of petroleum contaminated soil under cold climate conditions. Int Biodeter Biodegr. 2013 ; 85:375-82.

16. Smith E, Thavamani $P$, Ramadass $K$, Naidu R, Srivastava P, Megharaj M. Remediation trials for hydrocarbon-contaminated soils in arid environments: evaluation of bioslurry and biopiling techniques. Int Biodeter Biodegr. 2015: 101:56-65.

17. Okonofua ES, Babatola JO, Ojuri OO, Lasisi KH. Determination of suitable $\mathrm{TPH}$ remediation approach via MANOVA and inferential statistics assessment. Remediation. 2020;30:75-87.

18. Wang SY, Kuo YC, Hong A, Chang YM, Kao CM. Bioremediation of diesel and lubricant oil-contaminated soils using enhanced landfarming system. Chemosphere. 2016;164:558-67.

19. Petavy F, Ruban V, Conil P, Viau JY, Auriol JC. Two treatment methods for stormwater sediments-pilot plant and landfarming-and reuse of the treated sediments in civil engineering. Environ Technol. 2009;30:825-30. 
20. Giasi Cl, Morelli A. A landfarming application technique used as environmental remediation for coal oil pollution. J Environ Sci Heal A. 2003; 38:1557-68.

21. Hejazi RF, Husain T, Khan FI. Landfarming operation of oily sludge in and region-human health risk assessment. J Hazard Mater. 2003;99:287-302.

22. Khan Fl, Husain T, Hejazi R. An overview and analysis of site remediation technologies. J Environ Manage. 2004;71:95-122.

23. Brown LD, Cologgi DL, Gee KF, Ulrich AC. Bioremediation of oil spills on land. In: Fingas M, editor. Oil spill science and technology. 2nd ed. Cambridge: Gulf Professional Publishing; 2017. p. 699-729.

24. Besalatpour A, Hajabbasi MA, Khoshgoftarmanesh AH, Dorostkar V. Land farming process effects on biochemical properties of petroleumcontaminated soils. Soil Sediment Contam. 2011;20:234-48.

25. Widada J, Nojiri H, Omori T. Recent developments in molecular techniques for identification and monitoring of xenobiotic-degrading bacteria and their catabolic genes in bioremediation. Appl Microbiol Biot. 2002;60:45-59

26. Chien HY, Kao CM, Jou CJ, Yang PY, Huang CC. Application of enhanced bioremediation to clean up diesel-oil contaminated soils: laboratory microcosm study. J Biotechnol. 2008;136:678-87.

27. Brown DM, Okoro S, van Gils J, van Spanning R, Bonte M, Hutchings T, et al. Comparison of landfarming amendments to improve bioremediation of petroleum hydrocarbons in Niger Delta soils. Sci Total Environ. 2017;596-97: 284-92.

28. Maila MP, Cloete TE. Bioremediation of petroleum hydrocarbons through landfarming: are simplicity and cost-effectiveness the only advantages? Rev Environ Sci Biotechnol. 2004;3:349-60.

29. Heitzer A, Sayler GS. Monitoring the efficacy of bioremediation. Trends Biotechnol. 1993;11:334-43.

30. Liu SH, Zeng GM, Niu QY, Liu Y, Zhou L, Jiang LH, et al. Bioremediation mechanisms of combined pollution of PAHs and heavy metals by bacteria and fungi: a mini review. Bioresour Technol. 2017;224:25-33.

31. Adeniyi AA, Afolabi JA. Determination of total petroleum hydrocarbons and heavy metals in soils within the vicinity of facilities handling refined petroleum products in Lagos metropolis. Environ Int. 2002;28:79-82.

32. Bhattacharya M, Biswas D. Enhancement of waste engine oil biodegradation by optimization of media using factorial design study. Indian J Biotechnol. 2014;13:293-300.

33. Jasmine J, Mukherji S. Evaluation of bioaugmentation and biostimulation effects on the treatment of refinery oily sludge using $2^{n}$ full factorial design. Environ Sci-Proc Imp. 2014;16:1889-96.

34. Agarry SE, Ogunleye OO. Factorial designs application to study enhanced bioremediation of soil artificially contaminated with weathered bonny light crude oil through biostimulation and bioaugmentation strategy. J Environ Prot. 2012;3:748-59.

35. USEPA. SW-846 Test Method 3540C: Soxhlet Extraction. Washington, DC: US Environmental Protection Agency; 1996.

36. ASTM. Standard Practice for Extraction of Solid Waste Samples for Chemical Analysis Using Soxhlet Extraction. West Conshohocken: American Society for Testing and Materials; 2005.

37. Sepahi AA, Golpasha ID, Emami M, Nakhoda AM. Isolation and characterization of crude oil degrading bacillus spp. J Environ Health Sci. 2008:5:149-54

38. Montgomery DC. Design and analysis of experiments. 8th ed. Hoboken: Wiley \& Sons, Inc; 2008

39. Forthofer RN, Lee ES, Hernandez M. Biostatistics: a guide to design, analysis and discovery. 2nd ed. Burlington: Academic Press; 2007.

40. Meloun, M, Militky J. Statistical data analysis: a practical guide. New Delhi: Woodhead Publishing: 2011.

41. Tavares APA, Coelho MAZ, Agapito MSM, Coutinho JAP, Xavier AMRB. Optimization and modeling of laccase production by Trametes versicolor in a bioreactor using statistical experimental design. Appl Biochem Biotech. 2006;134:233-48.

42. Singh G, Ahuja N, Sharma P, Capalash N. Response surface methodology for the optimized production of an alkalophilic laccase from $\gamma$-proteobacterium JB. Bioresources. 2009;4:544-53.

43. Cook RD. Detection of influenctial observations in linear regression. Technometrics. 1977:19:15-18.

\section{Publisher's Note}

Springer Nature remains neutral with regard to jurisdictional claims in published maps and institutional affiliations.
Ready to submit your research? Choose BMC and benefit from:

- fast, convenient online submission

- thorough peer review by experienced researchers in your field

- rapid publication on acceptance

- support for research data, including large and complex data types

- gold Open Access which fosters wider collaboration and increased citations

- maximum visibility for your research: over $100 \mathrm{M}$ website views per year

At BMC, research is always in progress.

Learn more biomedcentral.com/submissions 